Citation/Atıf: Sevim E, Bozdeveci A, Pinarbaş M, Kekeçoğlu M, Akpinar R, Keskin M, Kolayli S, Karaoğlu SA. 2021. Antibacterial Effects of Anatolian Propolis on Paenibacillus larvae (Anadolu Propolisinin Paenibacillus larvae Üzerine Antibakteriyel Etkisi). Arı D./U. Bee J. 21(2):177-186, DOI: 10.31467/uluaricilik.976536

\title{
ANTIBACTERIAL EFFECTS OF ANATOLIAN PROPOLIS ON PAENIBACILLUS LARVAE
}

\author{
Anadolu Propolisinin Paenibacillus larvae Üzerine Antibakteriyel Etkisi
}

\author{
Elif SEVIM ${ }^{1}$, Arif BOZDEVECi², Müberra PINARBAŞ², Meral KEKEÇOĞLU ${ }^{3}$, Rahşan \\ AKPINAR $^{4}$, Merve KESKINN ${ }^{5}$, Sevgi KOLAYLI ${ }^{6}$, Şengul ALPAY KARAOGLU
}

\begin{abstract}
${ }^{1}$ Kırşehir Ahi Evran University, Faculty of Art and Science, Department of Molecular Biology and Genetic, Kırşehir, TURKEY, ORCID No: 0000-0002-6455-1333.

${ }^{2}$ Recep Tayyip Erdogan University, Department of Biology, Rize, TURKEY, ORCID No: 0000-0002-0729-9143, ORCID No: 0000-0001-6064-0673, ORCID No: 0000-0003-1047-8350, Corresponding author/Yazışma Yazarı E-mail: sengul.karaoglu@erdogan.edu.tr.

${ }^{3}$ Düzce University, Faculty of Art and Science Department of Biology, Düzce, TURKEY, ORCID No: 0000-0002-2564-8343

${ }^{4}$ Samsun Veterinary Control and Research Institute, Samsun, TURKEY, ORCID No: 0000-0003-0075-9247.

${ }^{5}$ Bilecik Seyh Edebali University, Vocational School of Health Services, Bilecik, TURKEY, ORCID No: 0000-0001-9365$334 \mathrm{X}$.

${ }^{6}$ Karadeniz Technical University, Department of Chemistry, Trabzon, TURKEY, ORCID No: 0000-0003-0437-6139.
\end{abstract}

Geliş Tarihi / Received: 30.07.2021 Kabul Tarihi / Accepted:20.09.2021ＤOI: 10.31467/uluaricilik.976536

\begin{abstract}
Paenibacillus larvae (P. larvae) is a pathogenic bacterium causing American Foulbrood Disease (AFB) in honeybee larvae. It is necessary to develop alternative strategies for the control of this disease due to the serious honeybee colonies loses and the use of antibiotics. Recent studies are aimed at the investigating natural fighting agents against $P$. larvae. In our study, it was aimed to demonstrate potential antibacterial efficacy of ethanol extract of Anatolian Propolis (EAP) against $P$. larvae strains PB35 and SV35 which were isolated in Turkey. The total phenolic content (TPC) and flavonoid content (TFC) of EEAP were determined as $181.73 \pm 5.20 \mathrm{mg}$ Gallic Acid Equivalents (GAE)/g, and $42.33 \pm 1.40 \mathrm{mg}$ Quercetin Equivalents $(Q E) / g$, respectively. It was found that EAP contains different amounts of ferulic, caffeic, coumaric acids, rutin, and caffeic acid phenethyl ester (CAPE). The antibacterial activity of the EAP was determined by using agar-well diffusion, microdilution, and Bioscreen $\mathrm{C}$ techniques. The Minimal Inhibition Concentration (MIC) values of the EAP were determined as $74.87 \mu \mathrm{g} / \mathrm{ml}$ against strain PB35 and SV35 using both microdilution and Bioscreen $\mathrm{C}$ teqnique. In both techniques, Minimal Bactericidal Concentration (MBC) values of the EAP were evaluated as 149 and $598.4 \mu \mathrm{g} / \mathrm{ml}$ against strain PB35 and SV35, respectively. The fact that EAP shows low concentrations of bacteriostatic (MIC) and bactericide (MBC) activity values against $P$. larvae strains, spore-forming bacilli, which are agents of AFB disease, suggests that it may be a potential source in AFB disease control.
\end{abstract}

Keywords: American Foulbrood, Anatolian Propolis, MBC, MIC, Paenibacillus larvae

Öz

Paenibacillus larvae (P. larvae), bal arısı larvalarında Amerikan Yavru Çürüklüğü hastalığına (AYÇ) neden olan patojenik bir bakteridir. $P$. Larvae tedavisinde kullanılan antibiyotikler bal arısı kolonilerinin ciddi kaybına neden olmakta ve bu nedenle antibiyotik kullanımına bağlı olarak bu hastalığın kontrolü için alternatif stratejiler geliştirmek gerekmektedir. Son çalışmalar, $P$. larvae'ya karşı doğal mücadele ajanlarını araştırmaya yöneliktir. Çalışmamızda Anadolu propolisi etanolik ekstresinin (EAP) 
Türkiye'de izole edilen $P$. larvae suşları PB35 ve SV35'e karşı potansiyel antimikrobiyal etkinliğinin ortaya konması amaçlanmıştır. EAP, toplam fenolik madde (TPC), flavonoid madde miktarları (TFC) ve bazı fenolik bileşikler açısından karakterize edilmiştir. Analizlere göre, EAP'nin total fenolik madde miktarı ve flavonoid madde miktarları sırasıyla 181,73 $\pm 5,20 \mathrm{mg}$ Gallik Asit Eşdeğeri (GAE)/g TFC olarak 42,33 $\pm 1,40$ mg Kuersetin Eşdeğeri (QE)/g ve farklı miktarlarda ferulik, kafeik, kumarik asitler, rutin ve kafeik asit fenetil ester (CAPE) içerdiği bulundu. EAP'nin antimikrobiyal aktivitesi, agar kuyu difüzyon, mikrodilüsyon ve Bioscreen $C$ teknikleri kullanılarak belirlendi. EAP'nin Minimal İnhibisyon Konsantrasyon (MIC) değerleri, hem mikrodilüsyon hem de Bioscreen $C$ tekniği kullanılarak PB35 ve SV35 suşuna karşı $74,87 \mu \mathrm{g} / \mathrm{ml}$ olarak belirlendi. Her iki teknikte de PB35 ve SV35 suşlarına karşı EAP'nin minimal bakterisidal konsantrasyon (MBC) değerleri sırasıyla 149 ve $598,4 \mu \mathrm{g} / \mathrm{ml}$ olarak belirlendi.

Anahtar kelimeler: Amerikan Yavru Çürüklüğü, Anadolu propolisi, MBC, MIC, Paenibacillus larvae

\section{GENIŞLETILMIŞ ÖZET}

Amaç: Dünyanın birçok yerinde koloni kaybına, toplu arı ölümlerine ve bal veriminin düşmesine neden olan çeşitli arı hastalıkları bulunmaktadır. Hastalıklar arasında en dikkat çekici olanlardan bir tanesi de Amerikan Yavru Çürüklüğü Hastalığıdır (AYÇ). Hastalık larva aşamasında arının orta bağırsak lümenini etkiler ve yetişkin arı hastalığına neden olmaz. Paenibacillus sp., gram pozitif, fakültatif anaerobik, katalaz negatif. endospor oluşturan bakterilerdir. Paenibacillus larvae kolonileri küçük, düzenli, çoğunlukla kaba, düz veya kabarık ve beyazımsı ile bej renklidir. Etkilenen larvada bir milyonun üzerinde spor üretebilir ve AYÇ oluşumuna neden olur. Oksitetrasiklin hidroklorür (OTC) gibi antibiyotiklerin kullanılması, etkilenen kolonilerin kaybının önlenmesi ve tedavisi için yaygın bir stratejidir. Ancak, antibiyotiklerin uzun süreli kullanımında çeşitli sorunlar oluşabilmektedir. Son zamanlarda bazı ülkelerde oksitetrasikline dirençli $P$. larvae izolatlarının olduğu birçok çalışmada gösterilmiştir. Bu nedenle, kovanlarda patojenik mikroorganizmaları kontrol etmek için propolis gibi doğal ürünlerin kullanımına artan bir ilgi vardır. Bu çalışmanın amacı, doğal bir kovan ürünü olan etanolik Anadolu propolis ekstraktının (EAP) $P$. larvae suşları (PB35 ve SV35) üzerindeki etkisini in vitro belirlemek ve AFB'nin kontrolü ve önlenmesi için alternatif bir ürün olarak etanolik Anadolu propolis ekstraktının kullanılabilirliğini araştırmaktır.

Gereç ve Yöntem: Yapılan bu çalışmada ham propolis Düzce Üniversitesi Arıcılık Uygulama ve Araştırma Merkezi'nden (DAGEM) 2016 yılında temin edildi. Ham propolis donduruldu, öğütüldü ve $\% 70$ 'lik etanol ile ekstrakte edildi. Hazırlanan ekstraktın toplam fenolik madde miktarı FolinCiocalteu metoduna göre belirlendi. Ayrıca etanolik propolis ekstraktının toplam flavonoid madde miktarı, antioksidan kapasitesi ve fenolik profili belirlendi. P. larvae PB35 ve SV35 suşları morfolojik, biyokimyasal ve moleküler özelliklerine göre tanımlandı. Daha sonra etanolik Anadolu propolis ekstraktının antibakteriyel aktiviteleri, agar-well difüzyon yöntemi kullanılarak $P$. larvae PB35 ve SV35 suşlarına karşı test edildi. Minimal inhibisyon derişimi ve minimal bakteriyosidal derişimi tespit edildi. Etanolik Anadolu propolis ekstraktının $P$. larvae PB35 ve SV35 popülasyonları, gecikme fazları ve üstel fazlar üzerindeki etkileri Bioscreen kullanılarak incelendi.

Bulgular: Yapılan analizler neticesinde etanolik Anadolu propolis ekstraktının total fenolik madde miktarının $181,73 \pm 5,20 \mathrm{mg} \mathrm{GAE} / \mathrm{g}$, total flavonoid madde miktarının $42,33 \pm 1,40 \mathrm{mg}$ QE/g olduğu ve propolis ekstraktının $p$-kumarik asit, ferulik asit, krisin ve pinocembrin bileşenleri açısından zengin olduğu tespit edildi. Etanolik Anadolu propolisinin $P$. larvae'ye ait iki farklı suş üzerine de etkili olduğu belirlendi

Sonuç: Bu çalışmanın sonuçları, etanolik Anadolu propolis ekstraktının AYÇ'yi ortadan kaldırmak için iyi bir potansiyele sahip olduğunu ve $P$. larvae tehdidine karşı doğal bir ilaç olabileceğini göstermektedir. Ayrıca spor oluşturan bir bakteri olan P. larvae'nin MBC değerlerinin elde edilmesi, AYÇ hastalık kontrolünde kullanım potansiyeline sahip olduğunu gösteren önemli bir sonuç olarak değerlendirilmektedir.

\section{INTRODUCTION}

In many parts of the world, there are various bee diseases which cause loss of colonies, collective bee deaths, and reduced honey yield. One of the 


\section{ARAŞTIRMA MAKALESI / RESEARCH ARTICLE}

most remarkable of among the diseases is the American Foulbrood Disease (AFB). This disease in many countries "forced notifiable" disease is on the list (Genersch 2010). The disease affects the middle gut lumen at the larval stage and does not cause disease of adult bee. Paenibacillus sp. in the Firmicutes Phylum and Bacillales Ordo are grampositive, facultative anaerobic, catalase negative endospore-forming bacteria. Paenibacillus larvae colonies were small, regular, mostly rough, flat or raised, and whitish to beige (Ash et al. 1993). It is a bacterium that can produce over one million spores in effected larva thus AFB occurs. A complete solution for the control and protection of the disease is not offered because bacterial spores can survive for a long time against physical conditions (Hrabák and Martínek 2007, Genersch 2010). Using antibiotics like oxytetracycline hydrochloride (OTC) is a common strategy for the prevention and treatment of affected colonies (Hansen and Brødsgaard 1999). However, there may be various problems with the extended use of these antibiotics. Recently many studies showed to be oxytetracycline resistant $P$. larvae isolates in some countries (USA, Canada, and Argentina) (Alippi 2000, Evans 2003).

Propolis is a natural bee product containing essential oils, waxes, phenolic, and flavonoids. Propolis is collected by honeybees from tree buds, leaf, and other botanical resinous sources for protection of hives from a number of threats. Propolis composition depends on mainly the botanical origin (Kuropatnicki et al. 2013, Baltas et al. 2016). There has been an increasing interest in the usage of natural products like propolis for controlling the pathogenic microorganisms in hives.

The aim of the study is to determine the effect of Ethanol Extract of Anatolian Propolis (EAP) on P. larvae strains and is to investigate the availability of EAP as an alternative product for the control and prevention of AFB. Until now, no one has tested Anatolian propolis extract against $P$. larvae using Bioscreen $C$ techniques. All microorganisms (bacteria, mold, yeast, etc.) increase the turbidity of the liquid growth medium when growing and multiplying in it. Bioscreen $\mathrm{C}$ monitors this growth by measuring the turbidity of the medium in the wells of a microplate. These measurements are done kinetically and recorded as optical density (OD) measurements (Anonymous 2016). In our study, the values of propolis extract stopping the development of $P$. larvae were determined by monitoring them with Bioscreen $\mathrm{C}$ at different concentrations.

\section{MATERIAL AND METHODS}

\section{Bacteria Strains and Propolis Sample}

Paenibacillus larvae ( $P$. larvae) PB35 and SV35 strains were obtained from Bee Diseases Laboratory, Samsun Veterinary Control Institute. The tested Anatolian Propolis sample was obtained from Düzce University Beekeeping Research, Development and Application Center (DAGEM) in Yığılca areas in Turkey, 2016. Raw propolis sample was obtained from directly plastic traps put under hive cover. The propolis sample was kept in a deep freezer $\left(-20^{\circ} \mathrm{C}\right)$.

\section{Identification of $\boldsymbol{P}$. larvae strains}

P. larvae PB35 and SV35 strains were identified according to their morphological, biochemical, and molecular characteristics. Properties of colony morphologies, Gram staining, endospore staining were used for morphological characterization of bacterial strains (CLSI 2015). For molecular analyses, 16S rRNA gene sequence was performed previously described by Sevim et al. (2017). The 16S rRNA sequences for $P$. larvae isolates were deposited in GenBank (NCBI, Bethesda, MD, USA) under accession numbers MW227606 (PB35) and MW227607 (SV35).

\section{Extraction of Anatolian Propolis}

Frozen raw propolis sample was grinded, and $5 \mathrm{~g}$ of powdered raw sample was dissolved in $50 \mathrm{~mL} 70 \%$ ethanol in a glass flask $(500 \mathrm{~mL})$, stirred on a shaker (Heidolph Promax 2020, Schwabach, Germany) at room temperature for 48 hours and after filtration, the extract was evaporated with a Rotary evaporator at $40^{\circ} \mathrm{C}$ (HEIDOLPH Hei-VAP Value Digital G3) and stored at $-20^{\circ} \mathrm{C}$ (Aliyazıcıoglu et al., 2013, Keskin et al. 2020).

\section{Determination of Total Phenolic and Flavonoid Content}

Total phenolic content of the Anatolian propolis was carried out according to Folin-Ciocalteu method (Singleton et al. 1999). The results were expressed as $\mathrm{mg}$ of gallic acid equivalents per $\mathrm{g}$ sample. Total flavonoid was measured by spectrometric assay (Fukumoto and Mazza 2000). The result was expressed as $\mathrm{mg}$ of quercetin equivalents (QE) per g sample. 


\section{ARAŞTIRMA MAKALESI / RESEARCH ARTICLE}

\section{Determination of Ferric Reducing Power Antioxidant Activity}

The FRAP method is the most commonly used method for determining the antioxidant capacity of natural products, and it is a method based on the reduction of iron(III) ion in the Fe(III)-TPTZ complex by antioxidants (Benzie and Strain, 1996). Fe(III), which is reduced by the antioxidant substances in the solution, gives absorbtion at $593 \mathrm{~nm}$. Results for FRAP activity were expressed as $\mu \mathrm{moL}$ $\mathrm{Fe}_{2} \mathrm{SO}_{4} .7 \mathrm{H}_{2} \mathrm{O} / \mathrm{g}$.

\section{Analyses of Phenolic Compounds in HPLC-UV}

Phenolic compounds of the propolis were analyzed according to method described by Can et al. (2015). $\mathrm{C}_{18}$ analytical column C $(150 \mathrm{~mm} \times 4.6 \mathrm{~mm}, 5 \mu \mathrm{m}$; Fortis) was used by gradient elution (Can et al. 2015). $2 \%$ acetic acid in water (A) and acetonitrile: water (70:30) (B) were utilized as mobile phase for elution. $25 \mu \mathrm{L}$ samples were injected at $30^{\circ} \mathrm{C}$ and flow rate at $0.75 \mathrm{ml} / \mathrm{min}$. Caffeic acid phenethyl ester (CAPE) compound was carried out the same colon with different analyses conditions (Can et al. 2015). A $0.1 \%$ formic acid in water and B $0.1 \%$ formic acid in acetonitrile and was monitored at $270 \mathrm{~nm}$ at $30^{\circ} \mathrm{C}$.

\section{Determination of Antibacterial Activity}

Antibacterial activities of EAP were tested against $P$. larvae PB35 and SV35 strains using the agar-well diffusion method. PB35 and SV35 strains were suspended in $3 \mathrm{~mL}$ of MYPG broth. These bacterial suspensions were diluted to $10^{6} \mathrm{cfu} / \mathrm{ml}$ and then were plated on the surface of MYPG agars. Wells of $5 \mathrm{~mm}$ in diameter were cut from the dried agar using a sterile cork-borer. Each well was filled with $50 \mu \mathrm{L}$ of EAP and the plates were incubated at $37^{\circ} \mathrm{C}$ for 48 h. Antibacterial activity was evaluated by calculating the clear zone of inhibition. Ampicillin $(10 \mu \mathrm{g})$ was used as a control antibacterial agent. As a solvent control, 1/2 dilution of analytical grade ethanol was used (Sevim et al. 2017).

\section{Determination of Minimal Inhibition Concentrations Value (MICs)}

MICs values were determined by microdilution technique (CLSI, 2015). The microdilution technique was performed in microtiter plates in MYPG broth. Ethanolic propolis extract was serially diluted in plate wells with MYPG broth. In fresh cultures of Paenibacillus larvae PB35 and SV35 strains, 0.5 McFarland turbidity suspensions were prepared.
Approximately 10 microliters of culture were added to each well containing serially diluted propolis extracts and incubated at $37^{\circ} \mathrm{C}$ for $48 \mathrm{~h}$ in order to determined MIC values. The MIC values were defined as the lowest concentration that showed no growth. Ampicillin $(10 \mu \mathrm{g} / \mathrm{mL})$ was used as a standard antibacterial agent. MYGB medium was used as negative control.

\section{Determination of Minimal Bacterisidal Concentration (MBC)}

The minimum bactericidal concentration (MBC) is the least concentration of antimicrobial agent required to kill microorganisms (Andrews 2001). The MBC was determined for ethanol extracts of Anatolian propolis. After MIC and Bioscreen C determination of the EAP tested, an aliquot of $10 \mu \mathrm{l}$ from all wells in which showed no bacterial growth was plated onto MYPG Agar plates without EAP. The plates were then incubated for 2 days at $37^{\circ} \mathrm{C}$. The MBC value was determined as the lowest EAP concentration without growth on MYPG Agar plates (Andrews 2001).

\section{Bioscreen $\mathbf{C}$ techniques}

The effects of EAP on the $P$. larvae PB35 and SV35 populations, lag phases and exponential phases were studied by using Bioscreen C (Labsystems, Helsinki, Finland) incubator. Triplicates of $360 \mu \mathrm{L}$ MYPG broth including serial dilution (1/2) concentration of EAP and $40 \mu \mathrm{L} 10^{6} \mathrm{cfu} / \mathrm{ml}$ bacterial concentrations were added in the wells of the Bioscreen plate. Plates were then placed on Bioscreen $\mathrm{C}$ incubator and then incubated at $37^{\circ} \mathrm{C}$. The optical density of the cell suspensions at $600 \mathrm{~nm}$ was monitored automatically in regular intervals of $30 \mathrm{~min}$ for 20 hours. Plates were shaken for 20 seconds before each measurement. The control wells contained the tested culture medium without EAP. The data were analyzed using the Excel software in Office 365 and by calculating the averages of three copies for each culture media type.

\section{RESULTS}

The PB35 and SV35 were isolated from the flower honey in the hives showing disease and honeycombs showing illness symptom, respectively. The strains were identified as $P$. larvae according to properties of morphological, biochemical, and 


\section{ARAŞTIRMA MAKALESI / RESEARCH ARTICLE}

molecular. The PB35 strain has a cream appearance, rough colony morphology, and terminal spore. The PB35 strain was negative with respect to catalase production, Voges-Proskauer, citrate, and starch hydrolysis test. The PB35 strain was able to metabolize maltose. The SV35 strain has transparent appearance, rough colony morphology and terminal spore. All biochemical test of the SV35 strain that was only able to metabolize glucose was negative. Two strains PB35 and SV35 have penicillin and ampicillin resistance. While the strains PB35 was resistant to chloramphenicol, the strains SV35 was resistant to tetracycline and norfloxacin. The partial sequences of the 16S rRNA gene were used for further characterization of the bacterial isolates. The obtained sequences were used for a Blast search in the NCBI database and phylogenetic analysis. Using 16S rRNA gene sequences, dendrogram was constructed and 2 isolates were identified as $P$. larvae (Figure. 1). Results obtained for the amount of total phenolic content and phenolic composition of propolis sample were summarized in Table 1. Effect of EAP on vegetative growth of PB35 and SV35 were given in Figure. 2 and Figure. 3.

Table 1. Characteristic properties of the Anatolian propolis.

Tablo 1. Anadolu propolisinin karakteristik özellikleri

\begin{tabular}{|c|c|c|}
\hline \multicolumn{2}{|c|}{ Total phenolic content (mg GAE/g) } & $181.73 \pm 5.20$ \\
\hline \multicolumn{2}{|c|}{ Total flavanoid (mgQE/g) } & $42.33 \pm 1.40$ \\
\hline \multicolumn{2}{|c|}{ Total antioxidant capacity (FRAP) $\mu \mathrm{moL} \mathrm{Fe}_{2} \mathrm{SO}_{4} .7 \mathrm{H}_{2} \mathrm{O} / \mathrm{g}$} & $680.70 \pm 6.80$ \\
\hline \multicolumn{3}{|c|}{ Phenolic Composition (HPLC-UV analyses) (mg/ 100g) } \\
\hline \multirow{7}{*}{ 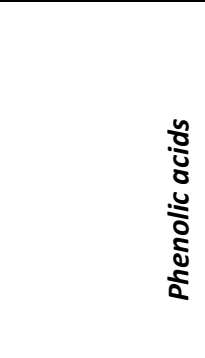 } & Gallic acid & - \\
\hline & Protocatechuic acid & 0.55 \\
\hline & p-OH benzoic acid & 6.0 \\
\hline & Caffeic Acid & 210 \\
\hline & Syringic Acid & - \\
\hline & p-coumaric acid & 124.0 \\
\hline & Ferulic acid & 42.5 \\
\hline \multirow{12}{*}{$\begin{array}{l}\frac{n}{0} \\
\frac{0}{0} \\
\frac{0}{4}\end{array}$} & $t$-cinnamic acid & 1.68 \\
\hline & Catechin & - \\
\hline & Rutin & 58 \\
\hline & Epicatechin & 6.40 \\
\hline & Resveratrol & - \\
\hline & Daidzein & 1.02 \\
\hline & Luteolin & 7.40 \\
\hline & Myricetin & - \\
\hline & Hesperetin & 4.20 \\
\hline & Chrysin & 46.80 \\
\hline & Pinocembrin & 50.04 \\
\hline & Caffeic acid phenethyl ester (CAPE) & 8.12 \\
\hline
\end{tabular}




\section{ARAŞTIRMA MAKALESI / RESEARCH ARTICLE}

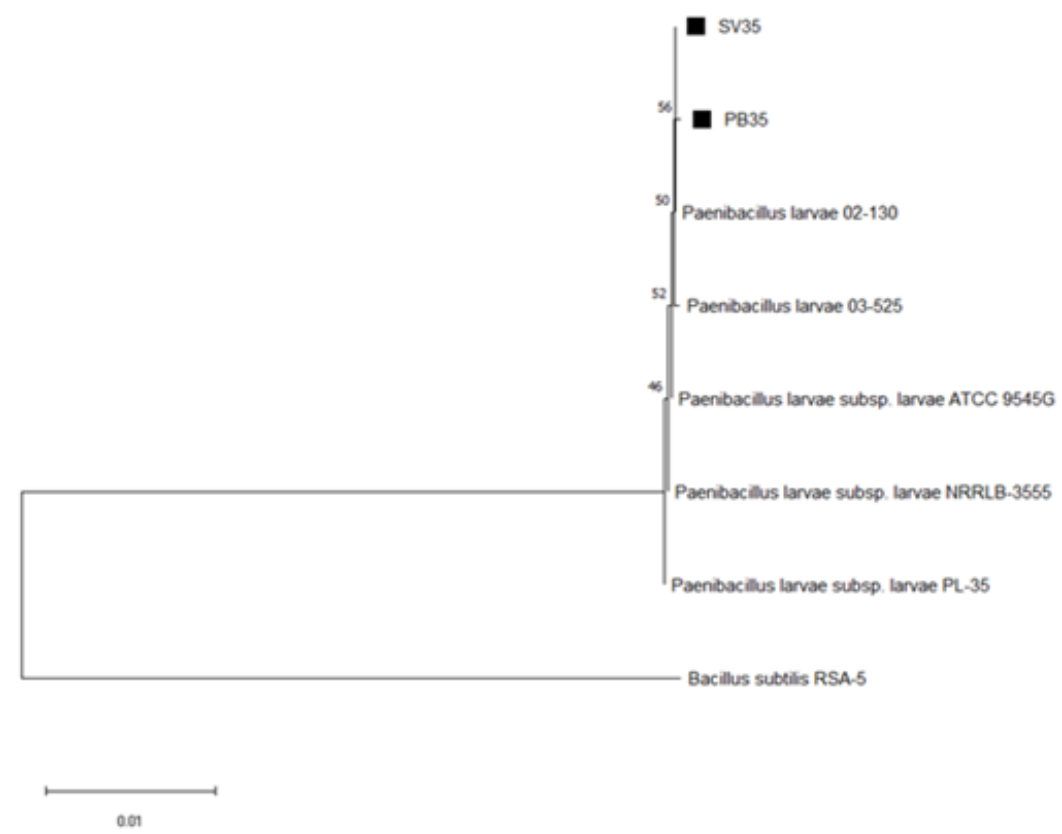

Figure 1. Phylogenetic analysis of the P. larvae PB35 and SV35 based on partial sequencing of the 16S rRNA gene. Neighborjoining analysis with p-distance method was used to construct the dendrogram. Bootstrap values shown next to nodes are based on 1000 replicates. $P$. larvae isolates are indicated with black squares. The scale on the bottom of the dendrogram shows the degree of dissimilarity. Bacillus subtilis RSA-5 was used as out group.

Şekil 1. 16S rRNA geninin kısmi dizilimine dayalı olarak $P$. larva PB35 ve SV35'in filogenetik analizi. Dendrogramı oluşturmak için p-mesafe yöntemiyle komşuluk analizi kullanıldı. Düğümlerin yanında gösterilen önyükleme değerleri, 1000 kopyayı temel alır. P. larva izolatları siyah karelerle gösterilmiştir. Dendrogramın altındaki ölçek, farklılığın derecesini gösterir. Dış grup olarak Bacillus subtilis RSA-5 kullanıldı.

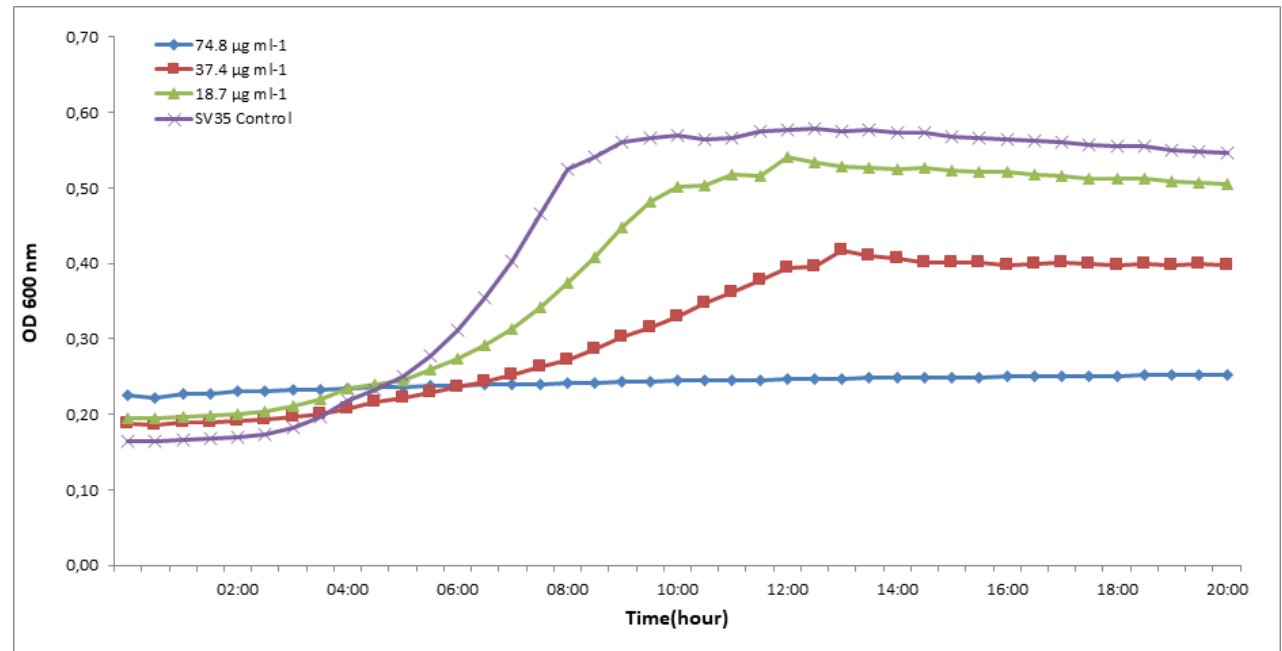

Figure 2. Effect of EAP on vegetative growth of SV35

Şekil 2. EAP'nin SV35'in vejetatif büyümesi üzerindeki etkisi 


\section{ARAŞTIRMA MAKALESI / RESEARCH ARTICLE}

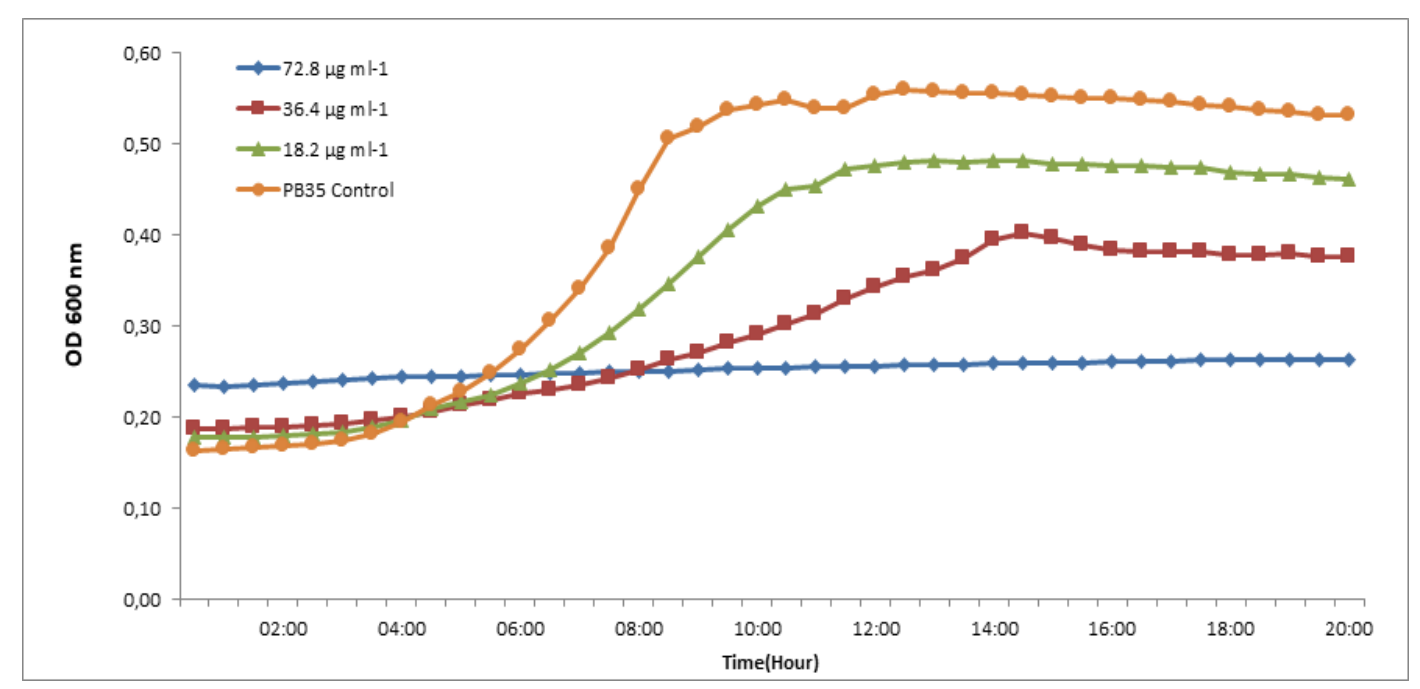

Figure 3. Effect of EAP on vegetative growth of PB35

Şekil 3. EAP'nin PB35'in vejetatif büyümesi üzerindeki etkisi

\section{DISCUSSION}

$P$. larvae are a major threat to hives. The infection of $P$. larvae cause a collapse in honeybee colonies. To protect the hives, it has been required effective antibacterial agents that do not leave residues in the bee products. For this reason, we tried to use Anatolian propolis as an antibacterial and prophylactic agent against $P$. larvae strains in this study.

$P$. larvae, caused AFB, is a serious problem in beekeeping worldwide and highly infectious. The spores of the pathogen are resistant to environmental conditions thus controlling the disease is more difficult. Adult worker bees, beekeeping equipment and products that are infected with $P$. larvae spores cause the spread of the disease within and among colonies. As a result, beekeepers often burn infected colonies to eliminate the source of infection (Bastos et al. 2008, Sevim et al. 2017). For beekeeping, the use of antibiotics is an alternative way to protect from AFB. Many antibiotics such as tetracycline derivatives (oxytetracycline and chlortetracycline), streptomycin, sulfonamides, tylosin, erythromycin, chloramphenicol, and lincomycin have been used to date. However, using them insensibly has led to both the accumulation of antibiotic residues in honey and in other hive products and to antibiotic resistant in strains of $P$. larvae. Therefore, the development of different methods such as the use of natural products to control AFB disease is crucial (Pellegrini et al. 2017, Sevim et al. 2017). It is known that propolis is a multifunctional honeybee product. Propolis extract has been identified as a natural alternative for controlling AFB (Antunez et al. 2008, Bastos et al. 2008). The inhibitory effect of propolis extract against $P$. larvae was attributed to the synergy between flavonoids and phenolic acids of propolis (Mihai et al. 2012). The higher phenolic contents have the higher biological active properties, as well as antimicrobial activity (Can et al. 2015, El Adaouia et al., 2020). When compared our result with different regions on propolis, Yığılca propolis contained a higher amount of total phenolic compounds than many samples (Bankova et al. 1995, Cabral et al. 2012, Rebiai 2015). Flavanoids have high pharmaceutical properties such as antioxidant, anti-inflammatory, and antimicrobial effects (Bankova et al. 1995, Salomão et al. 2004). In a study it has been reported there is a relationship between antimicrobial, bacteriostatic activities and phenolics of propolis (Baltas et al. 2016). The last studies have demonstrated that the inhibitory effect of propolis on bacteria depends on the synergism of many compounds in propolis. Mirzoeva et al. (1997) investigated the antibacterial activity of propolis ethanol extract. They concluded that this activity is highly related to the composition and concentration of propolis active compounds. Phenolic and flavonoid components of propolis were found to inhibit bacterial motility. It has been claimed that the 


\section{ARAŞTIRMA MAKALESI / RESEARCH ARTICLE}

antibacterial activity of propolis extracts is related to the chemical composition of flavonoids (Sforcin 2007). It has been reported that the interaction between the two major groups (flavones/flavonols and flavanones/dihydroflavonols) was particularly important in inhibiting growth of honeybee pathogens such as $P$. larvae by Mihai et al. (2012). The antimicrobial effect of propolis extracts with different floral origins was tested against $P$. larvae strains isolated in Brazil. It has been reported that the antimicrobial activity of propolis has a minimum zone diameter of $20-12 \mathrm{~mm}$ and minimal inhibitory concentration of 1.7 and $0.12 \mathrm{mg} / \mathrm{mL}$ (Bastos et al. 2008). In another study performed by Isidorov et al. (2017), the antimicrobial activity of propolis samples (poplar, birch, and wire poplar) collected in the European climate zone was tested against the $P$. larvae and their antimicrobial activity was compared. The researchers declared that not only phenolic compounds but also some other compound classes like phenylpropanoids, hydroxycinnamyl sesquiterpenols, glycerides, and benzoates had an effect against the AFB.

Due to the evolution of resistance against antibiotics used in the treatment of AFB, this research is a significant first step in the identification of possible new active compounds within Anatolian propolis in the treatment of AFB in honey bee colonies. In case of success, this alternative application for the treatment of AFB does not leave any residue in pollen, honey, or wax (Bogdanov 2006, Lopez et al. 2007). The Anatolian propolis seems to be one of the best candidates for AFB treatment because of non residue, non toxic, and a natural bee product.

In our study, it is thought that it is important to determine the values of propolis extract that stop the development of $P$. larvae PB35 and SV35 strains by monitoring them with bioscreen $\mathrm{C}$ at different concentrations. It is thought that the spore-forming bacteria that cause this and similar diseases will make important contributions in determining the possible doses that can be used to prevent the transition from environmental sources to the hive and to the larvae. It is known that probably bees also need propolis production in order to protect them from $P$. larvae and similar pathogens. Honeybees collect resins with antimicrobial properties from various plant species, mix them with varying amounts of beeswax, and bring them back to their colony as propolis. The collection of antimicrobial compounds from the environment and their incorporation into social nest architecture as propolis is reported to be an effective but relatively undiscovered colony-level defense against pathogens (Banskota et al. 2001).

\section{Conclusion}

In conclusion, the results of this study showed that EAP is rich in ferulic, caffeic, coumaric acids, rutin, and caffeic acid phenethyl ester (CAPE). It has a good potential to eliminate AFB by its compounds and could be a natural drug against the threat of $P$. larvae. In addition, obtaining $\mathrm{MBC}$ values of $P$. larvae, a spore-forming bacterium, was evaluated as an important result showing that it has a potential for use for AFB disease control.

Author contributions: Conceptualization; Şengül Alpay Karaoğlu, Elif Sevim, Arif Bozdeveci, Methodology; Şengül Alpay Karaoğlu, Rahsan Akpınar, Arif Bozdeveci, Müberra Pınarbaş Çetin, Merve Keskin, Elif Sevim, Meral Kekeçoğlu, Sevgi Kolaylı Writing - Original Draft; Şengül Alpay Karaoğlu, Arif Bozdeveci, Elif Sevim, Merve Keskin, Writing - Final Version; Şengül Alpay Karaoğlu, Elif Sevim, Merve Keskin, Funding Acquisition; Şengül Alpay Karaoğlu.

Funding: This work was supported by the Recep Tayyip Erdoğan University research fund (RTEUBAP 2015.53001.102.03.04. Thanks for their financial supports.

Ethical issue: No approval of research ethics committees was required to accomplish the goals of this study.

Conflict of Interest: No conflict of interest declared.

\section{REFERENCES}

Alippi, A.M. (2000). Is Terramycin losing its effectiveness against AFB? The Argentinian experience. Bee Biz, 11, 27-29. doi.org/10.1080/00218839.2004.11101124.

Aliyazıcıoglu, R., Sahin, H., Erturk, O., Ulusoy, E., Kolayli, S. (2013). Properties of phenolic composition and biological activity of propolis from Turkey. International Journal of Food Properties, 16(2), 277-287.

Andrews, J.M. (2001). Determination of minimum inhibitory concentrations. Antimicrob 


\section{ARAŞTIRMA MAKALESI / RESEARCH ARTICLE}

\author{
Chemother, \\ 48: \\ doi.org/10.1093/jac/48.suppl_1.5. \\ $5-16$.
}

Anonymous (2016). User's manuel Bioscreen C. Oy Growth Curves Ab Ltd., Available at http://www.bioscreen.fi/images/Bioscreen\%2 0User\%20Manual\%202015.pdf Accessed date: 10. 05. 2019.

Antúnez, K., Harriet, J., Gende, L., Maggi, M., Eguaras, M., Zunino, P. (2008). Efficacy of natural propolis extract in the control of American Foulbrood. Veterinary Microbiology, 131(3-4), 324-331. doi.org/10.1016/j.vetmic.2008.04.011.

Ash, C., Priest, F.G., Collins, M.D. (1993). Molecular identification of rRNA group 3 Bacilli (Ash, Farrow, Wallbanks and Collins) using a PCR probe test. Proposal for the creation of a new genus Paenibacillus. Antonie Van Leeuwenhoek, 64, 253-260. doi.org/10.1007/BF00873085.

Baltas, N., Karaoglu, S.A., Tarakci, C., Kolayli, S. (2016). Effect of propolis in gastric disorders, inhibition studies on the growth of Helicobacter pylori and production of its urease. Journal of Enzyme Inhibition and Medicinal Chemistry, 31(sup2), 46-50. doi.org/10.1080/14756366.2016.1186023.

Bankova, V., Christov, R., Kujumgiev, A., Marcucci, MC., Popov, S. (1995). Chemical composition and antibacterial activity of Brazilian propolis Zeitschrift für Naturforschung C, 50(3-4), 167-172. doi.org/10.1515/znc-1995-3-402.

Banskota, A.H., Tezuka Y., Kadota S. (2001). Recent progress in pharmacological research of propolis. Phytotherapy Research, 15, 561571. doi.org/10.1002/ptr.1029.

Bastos, E.M.A., Simone, M., Jorge, D.M., Soares, A.E.E., Spivak, M. (2008). In vitro study of the antimicrobial activity of Brazilian propolis against Paenibacillus larvae. Journal of Invertebrate Pathology, 97(3), 273-281. doi.org/10.1016/j.jip.2007.10.007.

Benzie I.F., Strain, J.J. (1996). The ferric reducing ability of plasma (FRAP) as a measure of antioxidant power: the FRAP assay. Analytical Biochemistry, 239(1), 70-76. doi: 10.1006/ abio.1996.0292.
Bogdanov, S. (2006). Contaminants of bee products. Apidologie, $\quad 37(1), \quad 1-18$. doi.org/10.1051/apido:2005043.

Cabral, I.S.R., Oldoni, T.L.C, Alencar, S.M.D., Rosalen, P.L., Ikegaki, M. (2012). The correlation between the phenolic composition and biological activities of two varieties of Brazilian propolis (G6 and G12) Brazilian. Journal of Pharmaceutical Sciences, 48(3), 557-564. doi.org/10.1590/S198482502012000300023.

Can, Z., Yildiz, O., Şahin, H., Asadov, A., Kolayli, S. (2015). Phenolic profile and antioxidant potential of propolis from Azerbaijan. Mellifera, 15(1), 16-28.

CLSI (2015). Methodes for dilution antimicrobial susceptibility test for Bacteria that grow aerobically; Approvard Tenth Edition. Available at https,//clsi.org/media/1632/m07a10_sample. pdf Accessed date: 18. 11. 2020.

El Adaouia Taleb, R., Djebli, N., Chenini, H., Sahin, H., Kolayli, S. (2020). In vivo and in vitro antidiabetic activity of ethanolic propolis extract. Journal of Food Biochemistry, 44(7), e13267.

Evans, J.D. (2003). Diverse origins of tetracycline resistance in the honey bee bacterial pathogen Paenibacillus larvae. Journal of Invertebrate Pathology, 83, 46-50. doi.org/10.1016/S0022-2011(03)00039-9.

Fukumoto, L.R., Mazza G. (2000). Assessing Antioxidant and Prooxidant Activities of Phenolic Compounds. J Agric Food Chem, 48, 3597-3604. doi.org/10.1021/jf000220w.

Genersch, E. (2010). American Foulbrood in honeybees and its causative agent, Paenibacillus larvae. Journal of Invertebrate Pathology, 103, 10-19. doi.org/10.1016/j.jip.2009.06.015.

Hansen, H., Brødsgaard, C.J. (1999). American Foulbrood, A review of its biology, diagnosis and control. Bee World, 80, 5-23. doi.org/10.1080/0005772X.1999.11099415.

Hrabák, J., Martínek, K. (2007). Screening of secreted proteases of Paenibacillus larvae by using substrate-SDS-polyacrylamide gel electrophoresis. Journal of Apicultural 


\section{ARAŞTIRMA MAKALESI / RESEARCH ARTICLE}

Research, 46, 160-164. doi.org/10.1080/00218839.2007.11101388.

Isidorov, VA., Buczek, K., Zambrowski, G., Miastkowski, K., Swiecicka, I. (2017). In vitro study of the antimicrobial activity of European propolis against Paenibacillus larvae. Apidologie, $\quad 48(3), \quad 411-422$. doi.org/10.1007/s13592-016-0485-z.

Keskin, Ş., Yatanaslan, L., Karlıdağ, S. (2020). Anadolu'nun farklı illerinden toplanan propolis örneklerinin kimyasal karakterizasyonu (Chemical characterization of propolis samples collected from different provinces of Anatolia). Uludağ Arı Dergisi - Uludağ Bee Journal, 20(1), 81-88. doi.org/10.31467/uluaricilik.714317.

Kuropatnicki, A.K., Szliszka, E., Krol, W. (2013). Historical aspects of propolis research in modern times. Evidence-Baset Complementary and Alternative Medicine, 2013, 964149. doi.org/10.1155/2013/964149.

Lopez, M.I., Feldlaufer, M.F., Williams, A.D., Chu, P.S. (2007). Determination and confirmation of nitrofuran residues in honey using LCMS/MS. Journal of Agricultural and Food Chemistry, 55(4), 1103-1108. doi.org/10.1021/jf0625712.

Mihai, C.M., Mărghitaş, L.A., Dezmirean, D.S., Chirilă, F., Moritz, R.F., Schlüns, H. (2012). Interactions among flavonoids of propolis affect antibacterial activity against the honeybee pathogen Paenibacillus larvae. Journal of Invertebrate Pathology, 110(1), 6872. Doi.org/10.1016/j.jip.2012.02.009.

Mirzoeva, O.K., Grishanin, R.N., Calder, P.C. (1997). Antimicrobial action of propolis and some of its components: The effects on growth, membrane potential and motility of bacteria. Microbiological Research, 152, 239
246. doi.org/10.1016/S0944-5013(97)800341.

Pellegrini, M.C., Alonso-Salces, R.M., Umpierrez, M.L., Rossini, C., Fuselli, S.R. (2017). Chemical composition, antimicrobial activity, and mode of action of essential oils against Paenibacillus larvae, etiological agent of American foulbrood on Apis mellifera. Chemistry \& Biodiversity, 14(4), e1600382. doi.org/10.1002/cbdv.201600382.

Rebiai, A. (2015). Evaluation of antioxidant capacity of propolis collected in various areas of Algeria using electrochemical techniques. Int $J$ Electrochem Sci, 10, 9641-9651.

Salomão, K., Dantas, A.P., Borba, C.M., Campos, L.C., Machado, D.G., Aquino Neto, F.R., de Castro, S.L. (2004). Chemical composition and microbicidal activity of extracts from Brazilian and Bulgarian propolis. Letters in Applied Microbiology, 38(2), 87-92. doi.org/10.1111/j.1472-765X.2003.01458.x.

Sevim, E., Baş, Y., Celik, G., Pinarbaş, M., Bozdeveci, A., Özdemir, T., Karaoğlu, Ş.A. (2017). Antibacterial activity of bryophyte species against Paenibacillus larvae isolates. Turkish Journal of Veterinary and Animal Sciences, 41(4), 521-531. doi.org/10.3906/vet-1611-70.

Sforcin, J.M. (2007). Propolis and the immune system: a review. Journal of Ethnopharmacology, $\quad 113, \quad 1-14$. doi.org/10.1016/j.jep.2007.05.012.

Singleton, V.L., Orthofer, R., Lamuela-Raventos, R.M. (1999). Analysis of total phenols and other oxidation substrates and antioxidants by means of Folin-Ciocalteu reagent. In Methods in Enzymology, 299, 152-178. doi.org/10.1016/S0076-6879(99)99017-1. 